\title{
RANCANG BANGUN APLIKASI GAME EDUKASI PEMBELAJARAN AKSARA LAMPUNG "AJO DAN ATU - BELAJAR AKSARA LAMPUNG", BERBASIS ANDROID DENGAN SISTEM MULTI-ENDING MENGGUNAKAN ENGINE REN'PY
}

\author{
Gigih Forda Nama ${ }^{1}$, Flesi Arnoldi ${ }^{2}$ \\ ${ }^{1}$ Teknik Informatika \\ ${ }^{2}$ Teknik Elektro \\ Universitas Lampung \\ Email: 1'gigih@eng.unila.ac.id, flesiarnoldi@gmail.com
}

(Naskah masuk: 1 Oktober 2016, diterima untuk diterbitkan: 26 Desember 2016)

\begin{abstract}
Abstrak
Perkembangan teknologi informasi saat ini berkembang sangat pesat. Teknologi tersebut banyak dimanfaatkan untuk berbagai keperluan, antara lain agar dapat terhubung dengan kerabat yang jauh, mencari informasi, dan game. Pada penelitian ini dilakukan pembangunan game edukasi pembelajaran aksara Lampung menggunakan metode extreme programming, dengan alat bantu Ren'Py engine. Game yang dikembangkan berdasarkan kebutuhan calon pengguna untuk belajar aksara Lampung. Dari hasil iterasi menggunakan extreme programming, telah menghasilkan sebuah game edukasi yang memiliki sistem multi-ending dan sistem point. Sistem ini dapat membantu pengguna untuk belajar aksara Lampung, game edukasi ini dikembangkan untuk perangkat smartphone Android yang memiliki sistem operasi minimal versi 2.3+ (gingerbread), sehingga game ini dapat dimainkan dimanapun dan kapan pun.
\end{abstract}

Kata kunci: game edukasi belajar aksara Lampung, multi-ending game, metode extreme programming

\begin{abstract}
Nowadays the development of information technology rapidly increase. The technology widely used for various purposes, such as to communicate with other family, seeking information, and games. In this research, the development of Lampung alphabet educational game using extreme programming methods, with Ren'Py engine tools. The games was developed based on the needs of potential users that learn Lampung alphabet. From the results of the extreme programming iteration, has produced an educational game that has a multiending system and point system. This system can help the user to learn Lampung alphabet, this educational game developed for Android smartphone devices that have a minimal operating system version 2.3+ (Gingerbread), this game can be played anywhere and anytime.
\end{abstract}

Key words: lampung alphabet educational game, multi-ending game, extreme programming method

\section{PENDAHULUAN}

Pemerintah Provinsi Lampung mewajibkan seluruh sekolah dasar dan menengah untuk memberikan mata pelajaran bahasa Lampung kepada seluruh siswanya. Biasanya pada masingmasing sekolah sudah memiliki Guru bahasa Lampung, mereka berkewajiban dalam memberikan pemahaman terhadap aksara Lampung dan penggunaannya dalam kehidupan sehari-hari. Dalam kenyataannya para Guru terutama di tingkat dasar sering mendapati minat belajar siswa yang rendah terhadap pelajaran bahasa Lampung.

Berdasarkan hasil pencarian tim peneliti pada beberapa artikel baik melalui internet mapun perpustakaan daerah belum banyak ditemukan hasilhasil penelitian metode terbaik dalam hal pengajaran bahasa Lampung. Padahal pada tingkat pendidikan dasar sangat mengandalkan penggunaan metodemetode yang aplikatif dan menarik. Pembelajaran yang menarik akan memikat anak-anak untuk terus dan betah mempelajari Bahasa Lampung. Apabila siswa sudah tertarik dengan pembelajaran maka akan membantu meningkatkan prestasi siswa dalam bidang bahasa. Di sebagian besar siswa, pembelajaran Bahasa Lampung dirasa membosankan karena mereka sudah merasa sulit menerima penyampaian materi karena dikemas kurang menarik sehingga secara tidak langsung siswa menjadi lemah dalam penangkapan materi tersebut, dan banyak anak anak sekarang yang 
kurang memahami aksara Lampung. Selain faktor penyampaian materi, proses pembelajaran bahasa Lampung juga terkendala dengan sedikitnya media ajar yang tersedia di sekolah, yang sebagian besar hanya mengandalkan buku saja.

Berawal dari permasalahan tersebut, maka dirancanglah suatu permainan yang dapat mendukung siswa tingkat dasar dalam belajar aksara Lampung sehingga menjadi lebih menarik dan anak akan menjadi lebih tertarik untuk mempelajarinya. Kelebihan tersebut juga akan berpengaruh pada kualitas belajar anak sehingga anak tidak merasa bosan. Sistem multi-ending juga diterapkan ke dalam permainan, sehingga anak dapat memilih jalur cerita mereka sendiri dan akan menghasilkan akhir cerita yang berbeda setiap jalur cerita yang mereka pilih sendiri.

Permainan yang dikembangkan ini memiliki kelebihan berupa tampilan yang menarik, karakter karakter dalam permainan dibuat lebih khas, memiliki sistem multi-ending, memiliki sistem points, dan adanya interaksi antara permainan dan pengguna. Selain itu, permainan ini dikemas ke dalam bentuk aplikasi telepon pintar atau smartphone berbasis Android, sehingga anak dapat memainkannya dimanapun dan kapan pun. Melalui aplikasi game edukasi ini diharapkan dapat menghasilkan terobosan baru dalam sistem belajar bahasa lampung yang lebih menarik dan efektif.

\section{TINJAUAN PUSTAKA}

\subsection{Game Edukasi}

Game edukasi atau biasa juga disebut sebagai edutainment, adalah bagian dari permainan komputer pendidikan yang mudah dikenali dengan struktur reward atau penghargaan yang jelas dalam permainan terpisah dari pengalaman pendidikan (Egenfeldt, 2015). Sedangkan tujuan dari game edukasi adalah untuk melibatkan dan memotivasi pemain melalui pengalaman langsung dengan dunia game. Permainan harus memberikan kemungkinan reflektif menjelajahi fenomena, pengujian hipotesis dan membangun obyek, untuk membuat game yang baik, alur permainan sangat penting. Namun, selain itu diperlukan juga penciptaan alur cerita yang baik, grafis dan suara yang sesuai, dan keseimbangan dalam permainan. Jika aspek ini diabaikan, tentu saja hanya tidak akan cukup jika hanya mengandalkan alur permainan yang baik (Kiili, 2004).

\subsection{Multi-Ending}

Berdasarkan kamus definisi Oxford, multi atau multiple memiliki arti: mempunyai atau melibatkan beberapa bagian, elemen, atau anggota. Sedangkan ending memiliki arti: akhir atau bagian final dari sesuatu. Dari definisi - definisi tersebut, maka dapat disimpulkan bahwa multi-ending memiliki arti: memiliki beberapa bagian akhir. Jika sebuah game memiliki multi-ending, maka game tersebut mempunyai beberapa jenis cerita akhir atau cerita akhir yang bercabang.

\subsection{Aksara Lampung}

Had Lampung dipengaruhi dua unsur, yaitu Aksara Pallawa dan Huruf Arab. Had Lampung memiliki bentuk kekerabatan dengan aksara Rencong, Aksara Rejang Bengkulu, aksara Sunda, dan aksara Lontara. Had Lampung terdiri dari huruf induk, anak huruf, anak huruf ganda dan gugus konsonan, juga terdapat lambang, angka dan tanda baca. Had Lampung disebut dengan istilah Kaganga ditulis dan dibaca dari kiri ke kanan dengan Huruf Induk berjumlah 20 buah (Aryantio, 2015).

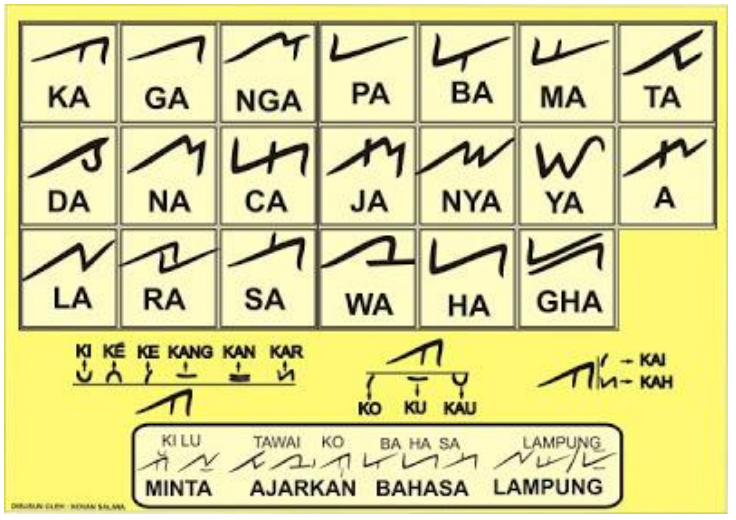

Gambar 1. Aksara Lampung (Aryantio, 2015)

\subsection{Python Programming Language}

Python merupakan bahasa pemrograman yang saat ini tengah populer dan banyak digunakan oleh peneliti dalam membangun aplikasi, dalam penelitian yang dilakukan oleh Gigih Forda Nama (Nama, G.F. dkk, 2014-2015) Python digunakan sebagai engine utama yang digunakan dalam pemrosesan data, Python terbukti berjalan baik dan stabil dalam pengembangan aplikasi web maupun mobile.

\subsection{Ren'Py}

Ren'Py adalah sebuah visual novel engine yang digunakan oleh banyak orang dari seluruh dunia, yang membantu kita menggunakan kata, gambar dan suara untuk menceritakan sebuah cerita interaktif yang dapat dijalankan pada perangkat komputer dan perangkat mobile seperti smartphone. Cerita interaktif bisa berupa visual novel dan game simulasi. Bahasa pemrograman yang mudah, membantu pengguna untuk menulis visual novel yang yang besar secara efisien, dimana bahasa pemrograman Python sendiri sudah cukup untuk game simulasi yang kompleks (Ren'Py, 2015). Ren'py merupakan program open source dan gratis digunakan untuk kepentingan komersial sehingga pengguna tidak perlu membayar kepada pihak pengembang aplikasi untuk menjual game yang telah dibuat dengan menggunakan Ren'py. Salah satu kelebihan besar Ren'py yaitu game yang dibuat 
dengan program ini dapat berjalan di hampir semua komputer. Tiga sistem operasi yang didukung oleh Ren'py yaitu Windows, Mac OS X, dan Linux, game yang dibuat dengan menggunakan Ren'py tidak tergantung software lain pada ketiga sistem operasi tersebut. Maka dari itu pengguna tidak perlu mengunduh runtimes, drivers, codecs, atau sejenisnya. Jika pemain mempunyai salah satu sistem operasi yang didukung, maka game yang dibuat oleh Ren'py dapat berjalan. Bahkan, jika tidak sekalipun, Ren'py ditulis dengan menggunakan teknologi portable seperti pygame, maka kemungkinan dapat dibuat untuk dijalankan (Ren'Py, 2015.

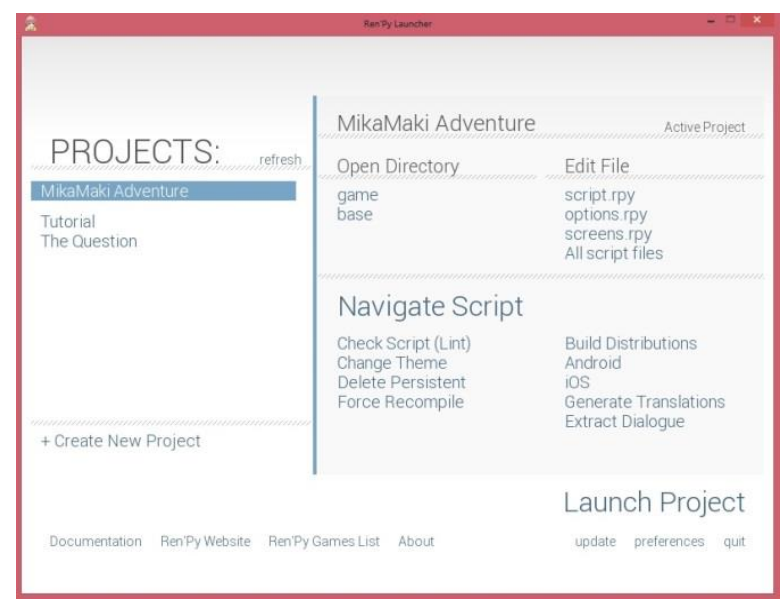

Gambar 2. Main Interface Ren'Py

\subsection{IDE (Integrated Development Environment) pada Ren'Py}

Pada dasarnya, Ren'Py hanyalah sebuah engine yang membantu pembentukan game serta memudahkan penulisan program (Ren'Py, 2015). Namun untuk menulis program tersebut, Ren'Py masih memerlukan program lain seperti teks editor Editra. Editra adalah editor teks multi-platform dengan implementasi yang berfokus pada menciptakan antarmuka yang mudah digunakan dan fitur yang membantu dalam pengembangan kode. Saat ini Editra mendukung sintaks dan berbagai fitur lain yang berguna untuk lebih dari 60 bahasa pemrograman. Editra tersedia secara bebas untuk digunakan di bawah Lisensi wxWindows. Saat ini proyek tersebut dalam tahap pengembangan alpha tetapi test builds dari titik "stabil" sudah tersedia untuk di-download dan dicoba pada sistem operasi Windows dan Mac OSX (Universal), saat ini sistem lain yang berbasis Unix dan Linux harus menginstal dari sumber menggunakan setup script yang telah disediakan (Editra, 2015).

\subsection{Extreme Programming (XP)}

XP adalah salah satu cara dalam mengembangkan sebuah software yang ringan, efisien, berisiko rendah, fleksibel, dapat diprediksi, cara ilmiah. Yang membedakan cara ini dengan metodologi lain adalah (Beck, 1999) :
1. Cepat, konkrit, dan umpan balik yang berkelanjutan dari sebuah siklus yang pendek.

2. Perencanaan yang bertahap yang dengan cepat datang dengan rencana keseluruhan yang diharapkan berkembang melalui kehidupan sebuah project.

3. Kemampuan membuat jadwal yang fleksibel pada implementasi dari fungsionalitas, dan merespon perubahan pada keperluan bisnis.

4. Ketergantungan pada tes secara otomatis yang ditulis oleh programmer dan customer untuk memantau kemajuan perkembangan, agar memungkinkan sistem untuk berkembang dan menangkap defect atau cacat program secara cepat.

5. Ketergantungan pada komunikasi lisan, test, dan source code untuk berkomunikasi pada struktur sistem.

6. Ketergantungan pada proses desain yang berevolusi sehingga dapat bertahan sepanjang sistem tersebut bertahan.

7. Ketergantungan pada kerjasama yang erat dari programmer dan kemampuan normal.

8. Ketergantungan pada latihan yang bekerja dengan baik dalam jangka pendek, naluri dari programmer, dan jangka panjang dari ketertarikan terhadap project.

Dalam metode Extreme Programming terdapat beberapa tahap pengembangan yang diilustrasikan dalam gambar berikut ini (Beck, 1999);

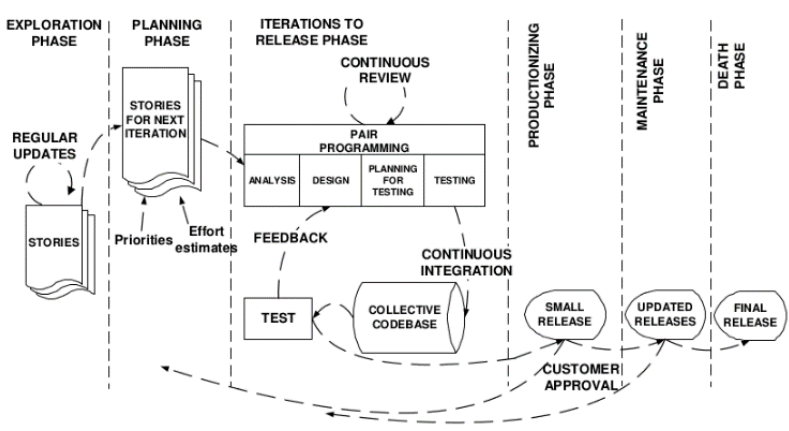

Gambar 3. Tahapan Extreme Programming (Candra, 2012)

\section{Tahap Explorasi (Exploration Phase)}

Pada tahap ini, peneliti menuliskan kebutuhankebutuhan dari sistem yang paling mendasar untuk mengumpulkan kebutuhan yang nantinya akan diimplementasikan pada suatu sistem. Informasi yang dikumpulkan berdasarkan pada kebutuhan dasar pada suatu game, serta informasi mengenai aksara Lampung.

\section{Tahap Perencanaan (Planning Phase)}

Tahap perencanaan berorientasi pada tahap eksplorasi. Pada Tahap ini peneliti memperkirakan 
kebutuhan user, kebutuhan operasi dan kebutuhan system. Maka pada tahap ini akan dihasilkan jadwal pelaksanaan proyek. Rancangan jadwal kegiatan yang dibuat memiliki tujuan untuk memberikan gambaran waktu pelaksanaan pembangunan sistem. Penentuan waktu pembangunan sistem yang terjadwal dimaksudkan untuk dijadikan batasan waktu dalam setiap tahapan proses pembangunannya.

\section{Tahap Iterasi (Iterations Phase)}

Proses iterasi yang dilakukan pada pembuatan Game Edukasi Ajo dan Atu - Belajar Bahasa Lampung ini mengacu pada Gambar 3. Iterasi terdiri dari tiga tahapan utama yaitu Analisis Sistem, Desain Sistem dan Pengujian Sistem.

\section{Analisis}

Tahap analisis merupakan tahap penting yang harus dilakukan sebelum memulai perancangan dan pembangunan sistem. Tahap analisis meliputi beberapa aspek, seperti menganalisis kebutuhan dari sistem, baik kebutuhan fungsional dan kebutuhan nonfungsional. Kebutuhan fungsional merupakan kebutuhan mengenai bagaimana suatu sistem melakukan proses kerjanya dan apa saja yang dihasilkan pada proses kerja yang dilakukan oleh sistem. Sedangkan kebutuhan nonfungsional adalah kebutuhan perangkat keras dan perangkat lunak yang digunakan oleh sistem.

\section{Desain}

Tahap ini dibuat dengan tujuan untuk memberikan gambaran dari game yang akan dibuat. Desain yang dilakukan pada tahap ini meliputi desain karakter dan desain interface dari game yang akan dibuat.

\section{Pengujian}

Pengujian ini meliputi pengujian fungsional dari game dan pengujian terhadap hal-hal yang terkait dengan game secara teknis. Hasil pengujian dianggap sebagai feedback dan jika terdapat hasil yang tidak sesuai akan segera diperbaiki pada iterasi selanjutnya.

\section{Tahap Produksi (Production Phase)}

Tahap ini merupakan tahap dimana release akhir dari pembangunan game. Bentuk release akhir yang dimaksudkan adalah peneliti menunjukkan keseluruhan game yang telah dibuat kepada user. Pada tahap ini juga akan terjadi pembaharuan sistem berdasarkan hasil yang didapat pada tahap pengujian akhir. Semua saran yang ada pada tahap pengujian diharapkan telah direalisasikan dalam bentuk perubahan sistem.

\section{Tahap Pemeliharaan (Maintenance Phase)}

Pada tahap ini dilakukan pengecekan akhir pada game. Di tahap ini juga dipastikan bahwa implementasi kebutuhan fungsional dan nonfungsional sistem telah terpenuhi. Jika syarat tersebut telah terpenuhi, maka game yang akan dibuat dapat dilanjutkan ke tahap publikasi.

\section{Tahap Publikasi Sistem (Death Phase)}

Tahapan ini merupakan tahapan akhir dalam pembangunan sistem yang telah diuji kemudian diimplementasikan sesuai dengan kebutuhan target. Game yang dihasilkan dalam penelitian ini akan disebarkan melalui media internet sehingga masyarakat dapat mengunduh game tersebut.

\section{Multimedia}

Multimedia adalah kombinasi dari teks, gambar, suara, animasi, dan video yang dikirimkan kepada pengguna oleh komputer atau elektronik lain atau cara manipulasi secara digital (Vaughan, 1993). Teknologi multimedia sangat diperlukan dalam pengembangan game edukasi.

\section{HASIL DAN PEMBAHASAN}

\subsection{Tahap Iterasi (Iterations Phase).}

Pada tahap ini telah melewati iterasi kedua. Pada iterasi kedua, desain mengalami beberapa perubahan antara lain:

\section{Karakter}

Pada iterasi kedua, desain karakter mengalami perubahan pada pakaian karakter. Desain pakaian karakter utama menggunakan motif tapis untuk memperlihatkan budaya Lampung.
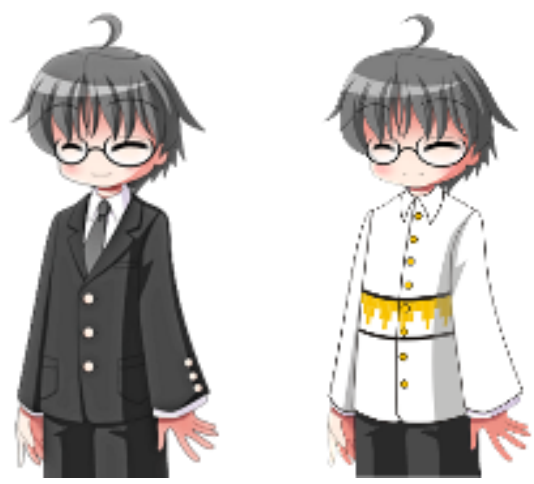

Gambar 4. Perubahan desain karakter utama

Selain itu, ada beberapa tambahan karakter seperti orang tua karakter utama.

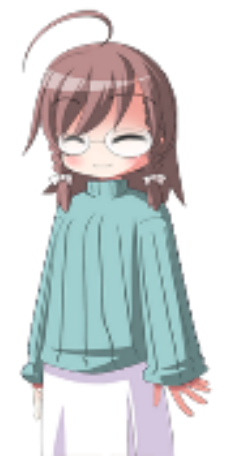

Gambar 5. Orang tua dari karakter utama 


\section{Interface}

Pada tahap ini, interface yang telah dirancang pada tahap desain, telah diimplementasikan ke dalam game. Dalam proses implementasinya, interface tidak mengalami perubahan dari desain awal. Pada implementasinya, coding interface berada pada file screens.rpy yang sengaja dibuat untuk menampung seluruh kode pemrograman interface pada game.

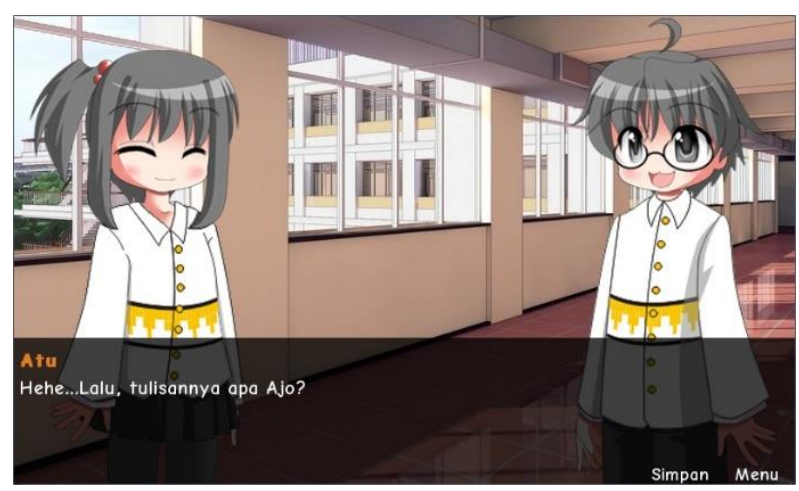

Gambar 6. Interface yang telah diterapkan kedalam game

\section{Background}

Pada desain background, peneliti menggunakan desain background yang telah disediakan dan bebas digunakan dari pihak Ren'Py. Desain karakter diunduh dari forum khusus developer yang menggunakan engine Ren'Py. Desain background yang diunduh berjumlah 35 items yang terdiri dari beberapa tempat dari ruangan-ruangan kelas, sekolah, beserta beberapa bagian diluar sekolah seperti tengah kota, jalanan, dan bangunanbangunan.

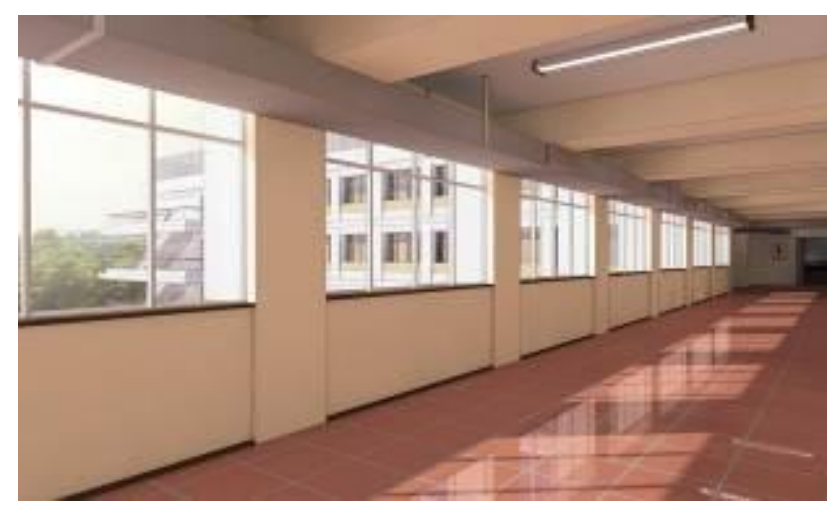

Gambar 4.4. Salah satu desain background yang digunakan di dalam game

\section{Jalur Cerita (Storyline)}

Pada game "Belajar Aksara Lampung ", jalur cerita memiliki percabangan cerita yang akan menuju pada 4 jenis ending. Tiap ending ditentukan dari jalur cerita yang dipilih oleh pemain dan total poin yang dikumpulkan oleh pemain selama permainan berlangsung. Poin didapatkan dari jawaban yang dipilih oleh pemain. Tiap jawaban benar maka akan sistem akan secara otomatis poin akan diakumulasikan sehingga didapatkan jumlah akhir yang akan menentukan arah ending permainan. Dalam permainan, terdapat 6 pilihan (choice) pada cerita. Dimana tiap bagian pilihan terdapat dua buah choice. Salah satu dari kedua choice adalah pilihan yang benar dan memiliki poin sebesar 5. Dengan begitu, pada akhir game, poin terbesar yang dapat dikumpulkan pemain adalah 30 .

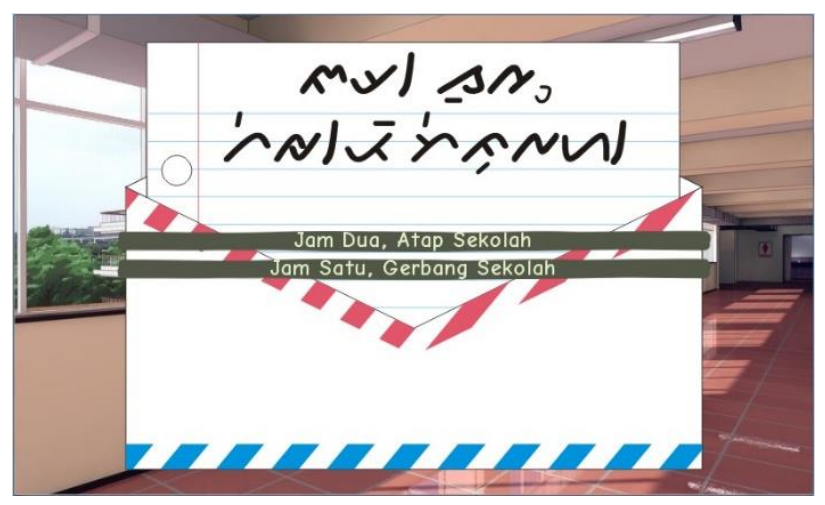

Gambar 7. Salah satu dari 6 choice yang ada dari game

Sama seperti jumlah ending yang ada, tiap ending pada game ini memiliki tipe yang berbeda-beda. Pada sistem multi-ending di game yang diterapkan, ending pertama harus dicapai dengan poin 30 yang berarti setiap pemain memilih choice harus semuanya tepat. Pada ending ini, Papa dari Ajo dan Atu akan pulang dan mengajak liburan ke objek wisata Pulau Pahawang. Tipe ending pertama ini adalah Great Ending.

Pada ending kedua, harus dicapai dengan poin 25 yang berarti 5 dari 6 choice yang dipilih harus benar. Pada ending ini, Papa dari Ajo dan Atu akan pulang dan mengajak liburan ke objek wisata Way Kambas. Tipe ending kedua ini adalah Good Ending.

Pada ending ketiga, harus dicapai dengan poin 20 yang berarti 4 dari 6 choice yang dipilih harus benar. Pada ending ini, Papa dari Ajo dan Atu akan pulang dan akan mengajak mengunjungi objek wisata Menara Siger. Tipe ending ketiga ini adalah Normal Ending.

Pada ending keempat, merupakan ending yang akan didapatkan pemain jika poin kurang dari atau sama dengan 15. Pada ending ini, Ajo dan Atu mengetahui identitas pengirim surat dan Papa dari Ajo dan Atu tidak akan pulang dalam jangka waktu 3 minggu. Tipe ending keempat ini adalah Bad Ending.

\section{Pengujian}

Pada tahap ini, peneliti melakukan pengujian ulang untuk memastikan tidak adanya bugs pada game setelah semua assets baru diaplikasikan kedalam game. Pengujian ini meliputi pengujian fungsional dari game dan pengujian terhadap hal-hal yang terkait dengan game secara teknis. Hasil pengujian dianggap sebagai feedback dan jika 
terdapat hasil yang tidak sesuai segera diperbaiki pada iterasi selanjutnya. Pengujian dilakukan pada beberapa perangkat, diantaranya yaitu Bluestack Android Emulator, Samsung Galaxy SL i9003, dan Nokia XL Dual SIM RM-1042. Beberapa pengujian yang dilakukan yaitu antara lain:

Tabel 1. Pengujian ulang pada game

\begin{tabular}{|l|l|l|}
\hline No. & Pengujian & Hasil yang Diharapkan \\
\hline 1. & $\begin{array}{l}\text { Menu pada } \\
\text { Startscreen }\end{array}$ & $\begin{array}{l}\text { Menu dapat berfungsi dengan } \\
\text { baik }\end{array}$ \\
\hline 2. & Asset & $\begin{array}{l}\text { Seluruh Asset dapat terlihat } \\
\text { saat permainan mulai tanpa } \\
\text { adanya kerusakan seperti } \\
\text { gambar hilang, kontras warna } \\
\text { berubah dan terpotong. }\end{array}$ \\
\hline 3. & Imagemaps & $\begin{array}{l}\text { Dots pada imagemaps berada } \\
\text { pada posisi yang seharusnya. }\end{array}$ \\
\hline 4. & Choice & $\begin{array}{l}\text { Percabangan cerita dapat jump } \\
\text { ke label yang seharusnya. }\end{array}$ \\
\hline 5. & Quickmenu & $\begin{array}{l}\text { Fungsi save, load dan auto dan } \\
\text { skip dapat berfungsi dengan } \\
\text { baik. }\end{array}$ \\
\hline 6. & Point & $\begin{array}{l}\text { Point dapat menampilkan nilai } \\
\text { yang sesuai dengan choice } \\
\text { yang dipilih oleh pengguna. }\end{array}$ \\
\hline
\end{tabular}

\subsection{Tahap Produksi (Production Phase)}

Tahap ini merupakan tahap dimana release akhir dari pembangunan game. Bentuk release akhir yang dimaksudkan adalah peneliti menunjukkan keseluruhan game yang telah dibuat kepada target. Pada tahap ini juga terjadi pembaharuan sistem berdasarkan hasil yang didapat pada tahap pengujian akhir. Semua saran yang ada pada tahap pengujian diharapkan telah direalisasikan dalam bentuk perubahan sistem. Pada tahap ini, Game Edukasi Belajar Bahasa Lampung ditunjukkan kepada murid dan guru Bahasa Lampung SMP Negeri 1 Bandar Lampung sebagai game tester atau penguji game. Selanjutnya, peneliti meminta Game Tester untuk memberikan saran kepada game yang diuji. Semua saran diharapkan dapat direalisasikan di tahap berikutnya.

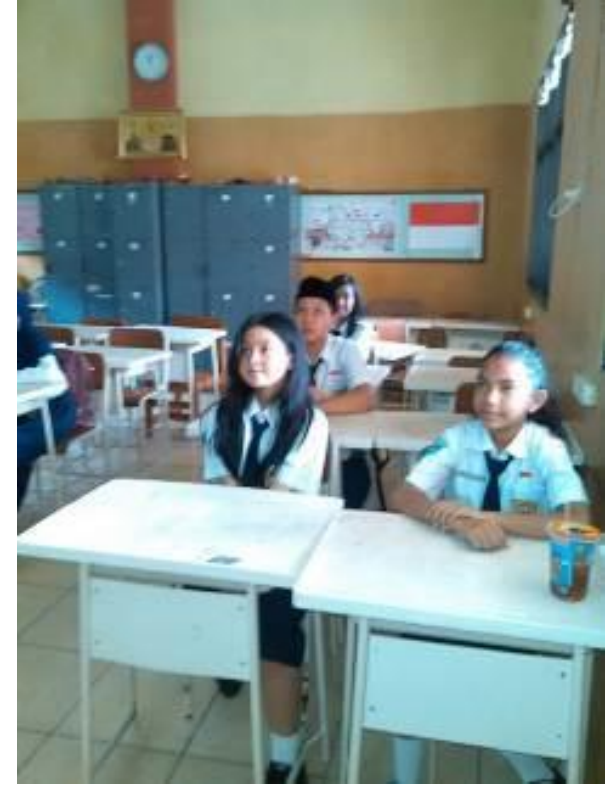

Gambar 8. Peserta Small-Release SMP Negeri 1 BDL

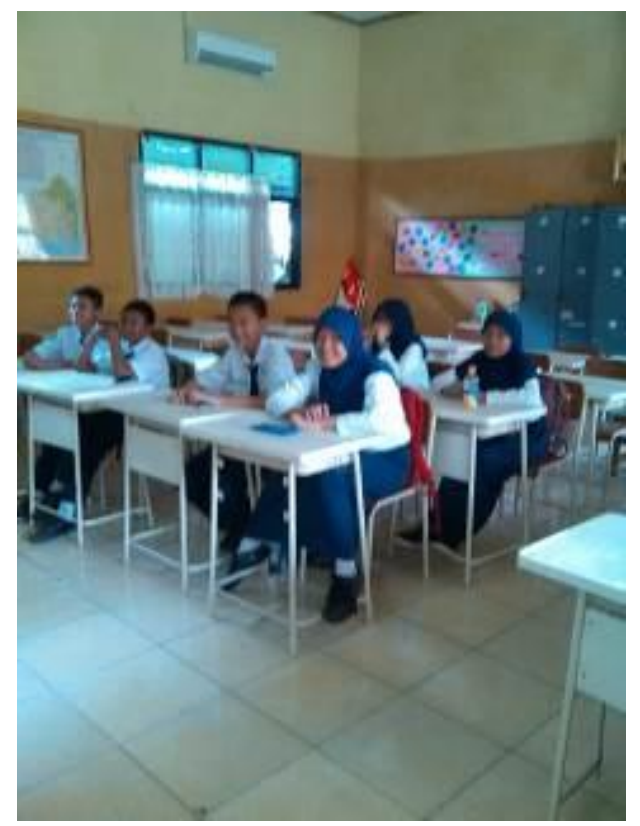

Gambar 9. Siswa SMP Negeri 1 sedang mencoba game edukasi Belajar Aksara Lampung 


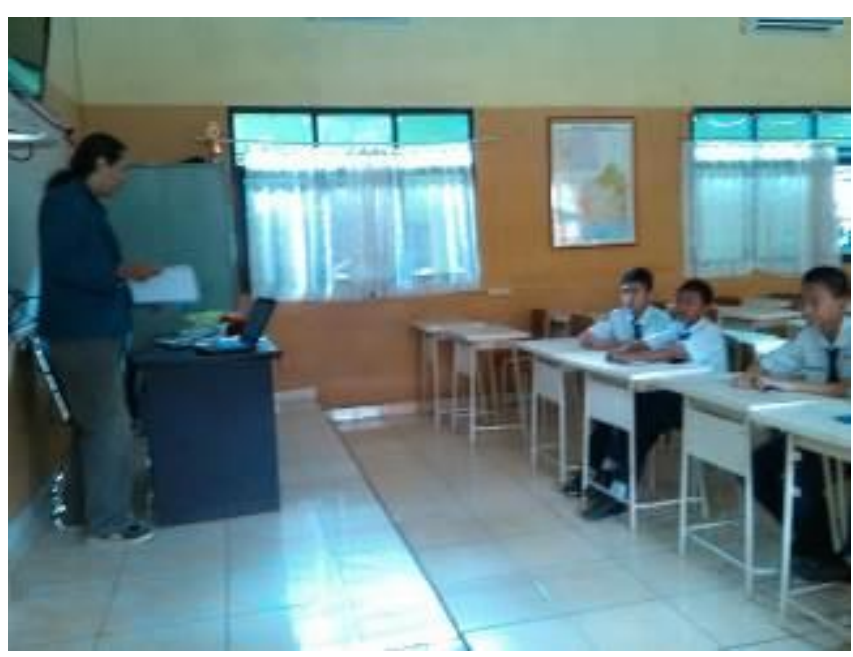

Gambar 10. Tim peneliti sedang menjelaskan cara penggunaan game edukasi Belajar Aksara Lampung

Setelah tim peneliti melakukan small release di SMP Negeri 1 Bandar Lampung , maka didapatkan beberapa hasil review. Hasil review yang didapatkan tersebut berupa saran dan penemuan bugs.

Tabel 2. Saran yang didapatkan setelah dilakukannya small-release

\begin{tabular}{|l|l|}
\hline No. & Saran \\
\hline 1 & $\begin{array}{l}\text { Size karakter terlalu kecil. Tidak sesuai } \\
\text { dengan besar layar } \\
\text { Pada bagian Anak Surat, Sebaiknya } \\
\text { ditambahkan penjelasan tiap posisi } \\
\text { pembacaan anak surat } \\
2\end{array}$ \\
3 & $\begin{array}{l}\text { Jumlah choice ditambahkan } \\
\text { Ukuran font sedikit lebih diperbesar } \\
\text { Pada Startmenu sebaiknya dipasang } \\
\text { gambar ikon Lampung. }\end{array}$ \\
\hline
\end{tabular}

Selain saran, pada saat melakukan small-release, peneliti menemukan dua buah bugs pada game. Berikut daftar bugs yang ditemukan:

Tabel 3. Bugs yang didapatkan setelah dilakukannya small-release

\begin{tabular}{|l|l|}
\hline No. & Bugs \\
\hline 1 & $\begin{array}{l}\text { Percabangan cerita nomor } 4 \text { mengalami } \\
\text { error. }\end{array}$ \\
2 & $\begin{array}{l}\text { Poin pada choice nomor } 4 \text { tidak ada sehingga } \\
\text { poin tidak bertambah walaupun memilih } \\
\text { jawaban benar }\end{array}$ \\
\hline
\end{tabular}

Semua saran dan bugs yang didapatkan peneliti dari hasil small-release ditinjau, diperbaiki dan segera diterapkan ke dalam game. Setelah memasuki tahap produksi dan mendapatkan hasil, peneliti mulai memasuki Tahap Pemeliharaan atau Maintenance Phase.

\subsection{Tahap Pemeliharaan (Maintenance Phase)}

Pada tahap ini pengembangan melakukan peninjauan dan perubahan kembali setelah melakukan small-release. Pada tahap Produksi sebelumnya, peneliti mendapatkan beberapa saran dan bugs yang diperbaiki di tahap ini. Seluruh saran dan bugs terdapat pada tabel 2. dan tabel 3 . Beberapa perubahan yang terjadi setelah semua saran dan bugs tersebut diterapkan dan diperbaiki yaitu :

\section{Size karakter}

Ukuran karakter sebelum dilakukan perubahan yaitu memiliki tinggi 450 pixel. Perubahan dilakukan dengan menggunakan software Adobe Photoshop CS5. Setelah dilakukan perubahan, ukuran tinggi karakter menjadi 500 pixel.

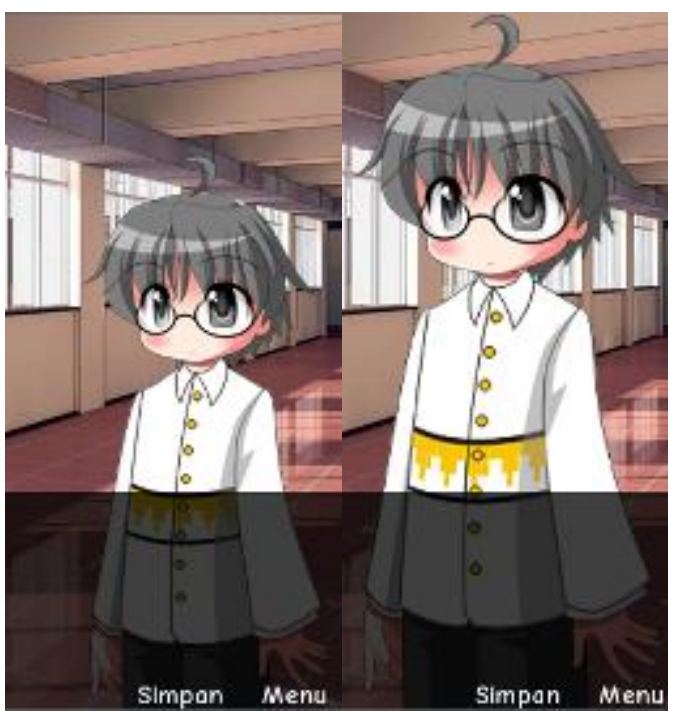

Gambar 11. Perbandingan ukuran karakter dengan tinggi 450 pixels (kiri) dan 500 pixels (kanan)

\section{Petunjuk anak surat}

Pada bagian anak surat, awalnya telah memiliki petunjuk cara membaca anak surat. Namun setelah dilakukan small-release, didapatkan bahwa murid masih sedikit kesulitan dan belum benar-benar mengerti cara membaca anak surat tersebut.

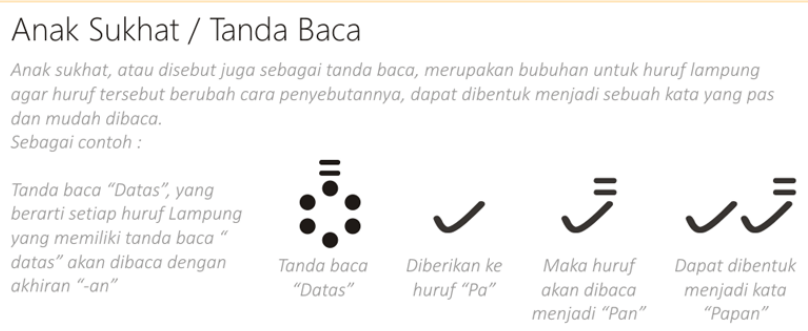

Saya Mengerti. Lanjut.

Gambar 12. Cara membaca anak surat 
Dari hasil tersebut, peneliti memutuskan untuk menambahkan petunjuk berupa penjelasan lebih detil cara pembacaan anak surat. Petunjuk baru ini dibuat dengan menggunakan software CorelDraw X4. Petunjuk baru diletakkan tepat setelah petunjuk cara membaca anak surat seperti yang ditunjukkan pada gambar 13 .

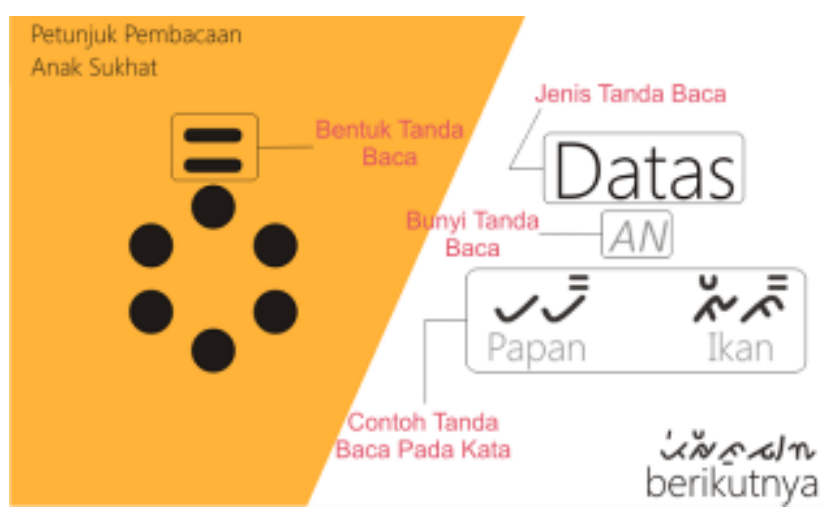

Gambar 13. Petunjuk pembacaan anak surat dengan deskripsi penjelasan

\section{Jumlah Pilihan (Choice)}

Pilihan atau choice yang diterapkan sebelum dilakukannya small-release berjumlah 4 pilihan. Namun setelah dilakukannya small-release, didapatkan hasil bahwa 4 pilihan terlalu sedikit. Maka peneliti beserta murid memutuskan untuk menambahkan choice menjadi 6. Awal total point terbesar berjumlah 20. Dengan dirubahnya jumlah choice maka jumlah total poin terbesar juga berubah menjadi 30.

\section{Ukuran Font (Font Size)}

Sebelum dilakukannya small-release, ukuran font dengan size 15 memiliki masalah berupa terlalu kecilnya tulisan pada layar smartphone dengan ukuran 480x800 pixel. Maka peneliti melakukan perubahan pada font size yang awalnya 15 menjadi 20.

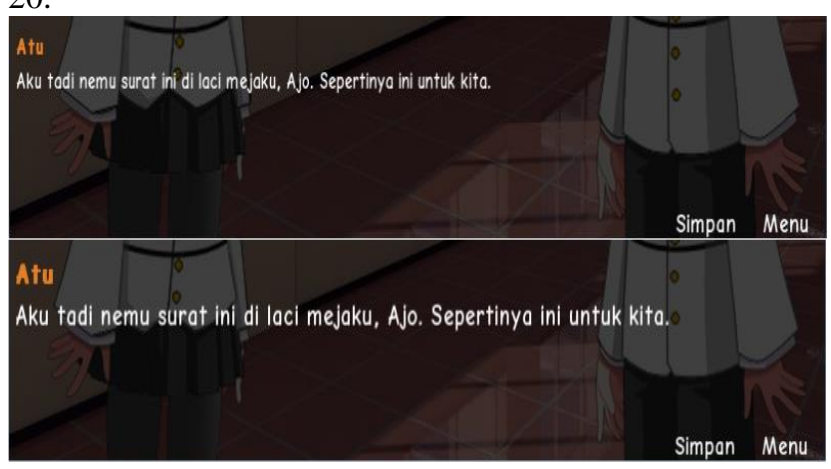

Gambar 14. Perbandingan antara Text size 15 (atas) dengan Text size 20 (bawah)

\section{Startscreen}

Sebelumnya, game ini hanya menggunakan warna hijau pastel polos (code hex $=\# 00$ cc99) yang merupakan warna dari template yang telah disediakan oleh engine Ren'Py. Setelah dilakukannya small-release, didapatkan bahwa startscreen sebaiknya dipasangkan gambar ikon Lampung. Maka dari itu peneliti menggunakan gambar Menara Siger pada startscreen.

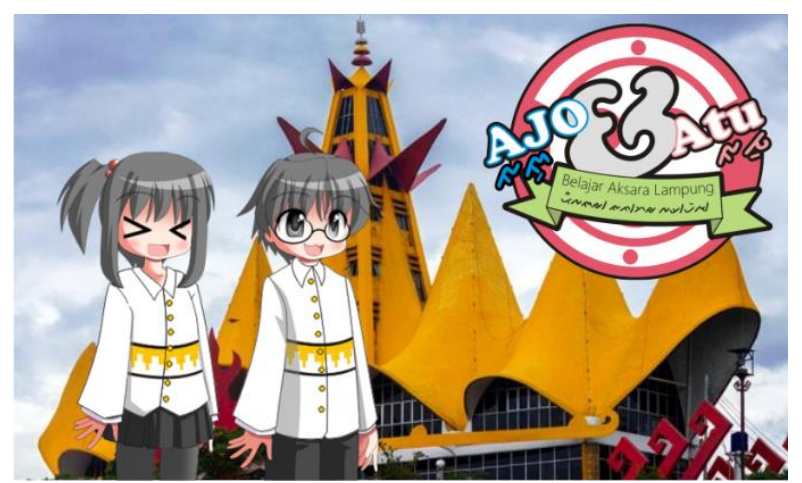

Gambar 15. Startscreen menggunakan gambar Menara Siger

\section{Percabangan Cerita}

Pada saat dilakukannya small-release, ditemukannya bugs pada percabangan cerita nomor 4. Bugs ini membuat game yang sedang dijalankan akan mengalami pesan error. Hal ini dikarenakan pada saat melakukan percabangan cerita, sistem harus mencari kode tujuan dari perintah jump. Error terjadi karena tidak ditemukannya label dari tujuan perintah jump. Peneliti telah memperbaiki label tujuan dari perintah jump. Dengan begitu tujuan percabangan cerita nomor 4 dapat berjalan dengan baik. Selain adanya error pada percabangan cerita, ada bugs lain yang terdapat pada percabangan cerita nomor 4. Percabangan cerita selalu terjadi pada menu choice sehingga jika pemain memilih salah satu choice, pemain akan diarahkan ke alur cerita yang sesuai dengan pilihan sebelumnya. Pada tiap choice tersebut, salah satu nya terdapat jawaban yang benar dan point akan terakumulasi karena adanya perintah " $\$$ point $+=5$ " pada jawaban yang benar. Namun, pada percabangan cerita nomor 4, peneliti tidak memasukkan perintah " $\$$ point $+=5$ " sehingga poin tidak terakumulasi sebagaimana mestinya. Setelah menemukan dimana letak kesalahan, peneliti menambahkan perintah tersebut kedalam salah satu choice yang benar sehingga point dapat terakumulasi.

\section{Test Aplikasi}

Pada tahap maintenance, peneliti juga diharuskan untuk mengetes langsung game yang telah dibuat ke dalam perangkat Android. Pada kali ini peneliti menggunakan Bluestack Android emulator untuk testing game yang telah di-build dengan menggunakan engine Ren'Py. 


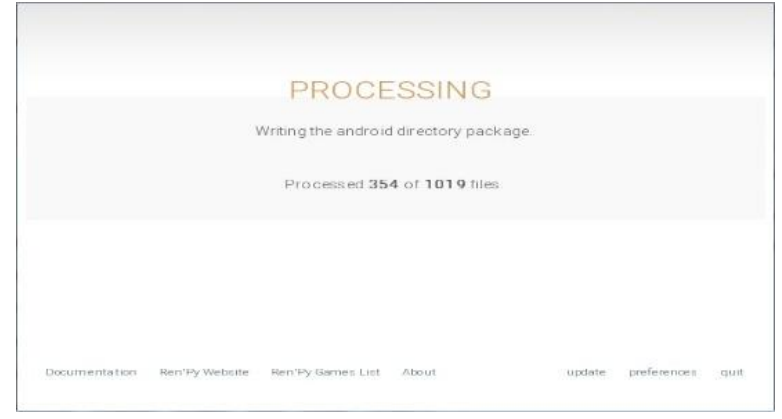

Gambar 16. Proses build game pada engine Ren'Py

Setelah proses build selesai, peneliti melakukan proses install pada Bluestack Android emulator. File hasil build dari engine Ren'Py memiliki ekstensi .apk. Dengan adanya Bluestack Android emulator yang telah terinstall, Peneliti cukup mengklik file .apk tersebut 2 kali dan aplikasi terinstall secara otomatis pada Bluestack.

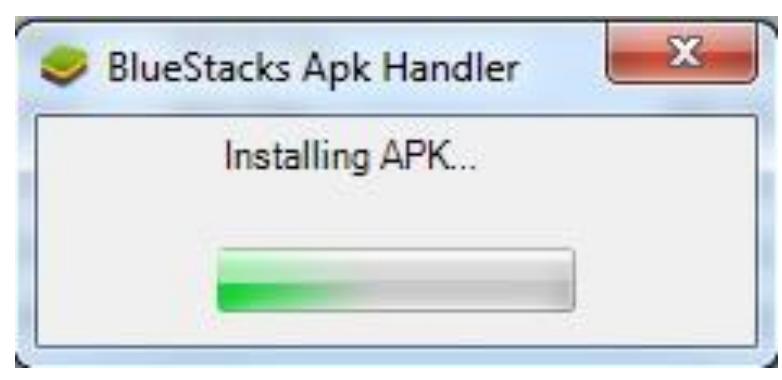

Gambar 17. Bluestack Android emulator melakukan proses instalasi aplikasi

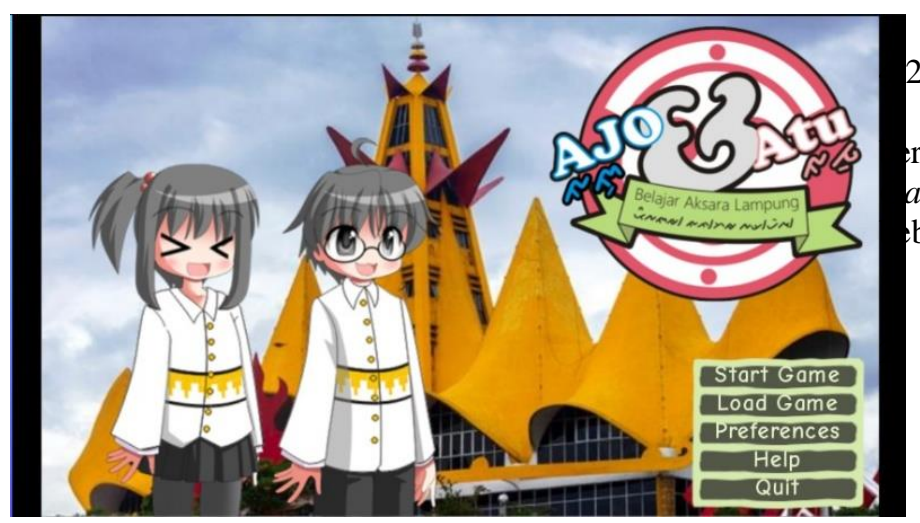

Gambar 18. Proses instalasi game pada Bluestack berhasil

\subsection{Tahap Publikasi Sistem (Death Phase)}

Pada tahap publikasi atau death phase, game yang telah dibuat sudah selesai dan siap untuk memasuki tahap release atau yang biasa disebut dengan "Master Up". Di tahap ini, game sudah tidak ada lagi yang harus diperbaiki karena game yang telah release sudah sempurna dan telah melalui proses pengujian sehingga tidak ditemukan lagi adanya bugs dan error. Untuk melakukan release, peneliti menggunakan platform Google-drive. Dengan menggunakan Google-drive, peneliti tidak memerlukan mengeluarkan biaya untuk melakukan release seperti pada Play Store milik Google. Peneliti juga dapat memuat lebih banyak informasi mengenai game yang dibuat. Jika peneliti memutuskan untuk mengembangkan sequel dari game yang dibuat, peneliti dapat melakukan release di tempat yang sama. Untuk proses upload file game yang memiliki ekstensi .apk.

\section{KESIMPULAN DAN SARAN}

\subsection{Kesimpulan}

Berdasarkan hasil perancangan dan implementasi Game Edukasi Belajar Aksara Lampung ini dapat ditarik kesimpulan sebagai berikut:

1. Game Edukasi yang dibangun ini dapat digunakan untuk media pembelajaran Aksara Lampung.

2. Menurut hasil survey pada saat small-release, $80 \%$ dari seluruh peserta survey menunjukkan bahwa game edukasi ini memiliki tampilan yang simpel dan mudah dimengerti oleh pengguna.

3. Game Edukasi dapat dimainkan dimanapun dikarenakan game berekstensi .APK yang dapat di install di perangkat yang memiliki OS Android versi $2.3+$.

4. Ada nya sistem Multi-Ending membuat pengguna lebih tertarik untuk terus mencoba mencari ending yang lain sehingga pengguna dapat lebih mudah belajar karena mengulang permainan berkali-kali.

\section{. Saran}

Berdasarkan pengalaman selama rlangsungnya perancangan dan implementasi ame Edukasi Belajar Aksara Lampung ini terdapat berapa saran sebagai berikut:

Perbanyak choice pada setiap jalur cerita sehingga permainan menjadi lebih menantang. Melakukan release di Play Store sehingga game yang dibuat menjadi lebih dikenal dan lebih mudah didownload.

Perbanyak varian Ending sehingga pengguna dapat melakukan lebih banyak eksplorasi cerita yang akan membuat pengguna lebih mudah belajar aksara Lampung.

4. Lebih perbanyak tentang sejarah dan pariwisata Lampung sehingga lebih mengenalkan Lampung pada pengguna.

5. Saat ini, Game edukasi yang dibuat menggunakan layout interface yang disediakan oleh Ren'Py. Menggunakan Custom Interface pada game dapat membuat tampilan menjadi lebih menarik. 


\section{DAFTAR PUSTAKA}

ARYANTIO, A. \& MUNIR, R. 2015. Pengenalan Aksara Lampung Menggunakan Jaringan Syaraf Tiruan. Makalah KNIF, 34-38.

BECK, K. 1999. Extreme Programming Explained: Embrace Change. (First Edition, ISBN 0201616416), Addison-Wesley Longman Publishing Co., Inc., Hal. 9.

CANDRA, B.A. 2012. Rancang Bangun Sistem Informasi Manajemen Terpadu (SIMANTEP) Online PT. PLN (Persero) Sektor Pembangkitan Tarahan Lampung Dengan Metode Extreme Programming. Jurnal Komputasi, Vol 1, No. 1, 31-24.

DESPA, D. \& KURNIAWAN, A. \& KOMARUDIN, M. \& MARDIANA \& NAMA, G. F. 2015. Smart monitoring of electrical quantities based on single board computer BCM2835. $2^{\text {nd }}$ International Conference on Information Technology, Computer, and Electrical Engineering, pp 315-320, Indonesia.

EDITRA 2015. Welcome to Editra.org, http://www.editra.org/.

EGENFELDT, N. S. 2015. Making sweet music: The Educational Use of Computer Games. Url:http://www.egenfeldt.eu/papers/sweet_ music.pdf, diakses 16 Desember 2015.

KIILI, K. 2004. Digital game-based learning: Towards an experiental gaming model. Internet and Higher Education 8, 13-24.

NAMA, G. F. \& ULVAN, M \& ULVAN, A. \& HANAFI, A. M. 2015. Design and Implementation of Web-Based Geographic Information System for Public Services in Bandar Lampung City - Indonesia. International Conference on Science in Information Technology (ICSITech), pp 270-275, Yogyakarta, Indonesia.

NAMA, G. F. \& KOMARUDIN, M. \& SEPTAMA, H. D. 2015. Performance Analysis of ArubaTM Wireless Local Area Network Lampung University. International Conference on Science in Information Technology (ICSITech), pp 41-46, Yogyakarta, Indonesia.

NAMA, G. F. \& KOMARUDIN, M. \& PRIAMBODO, H. \& MARDIANA \& SEPTAMA, H. D. 2014. Electricity, Temperature, and Network Utilization Monitoring at Lampung University Data Centre Using Low Cost Low Power Single Board Mini Computer. Regional Conference On Computer Information Engineering, Indonesia, pp. 184-189.

REN'PY. $2015 . \quad$ Why Ren'Py? http://www.renpy.org/why.html.
VAUGHAN, T. 1993. Multimedia: Making It Work. (first edition, ISBN 0-07-881869-9), Osborne/McGraw-Hill, Berkeley, Hal. 3. 